зображенні: глобус, смолоскип, книга, флейта Пана. Предмети володіють символічним значенням і їхня поява на будівлі однозначно мала на меті викликати образні асоціації.

Ще однією цікавою та естетично довершеною $є$ сюжетна сценка на фасаді споруди по вул. Пильникарській, 4. Сьогодні, це багатоквартирний житловий будинок. Оскільки даних про нього обмаль, виділимо те, що можемо виокремити із зображення. Як у попередньому зразку, на двох типах панно зображені путті, які в одному випадку представлені у вигляді будівельників, а в іншому - музикантів. В кожному 3 варіантів задіяно по чотири персонажі. Якщо у попередньому прикладі поєднувались наука і культура, то тут на одному будинку уживаються доволі полярні сфери.

Музичні сюжети в оздобі архітектурних споруд у Львові на зламі XIX - XX ст. демонструють широке різноманіття образів і тем, а їх детальне дослідження здатне розкрити цікаві і невідомі факти культурної історії міста.

\title{
Література:
}

1. Бірюльов Ю. Мистецтво Львівської сецесії. - Львів: Центр Європи, 2005. - 184 с.

2. Вулиці Львова. URL: https://streets.lvivcenter.org/uk/

3. Николишин Ю. Путівник по Львову. - Львів: Апріорі, 2016. - 96 с.

4. Студницька М. Синтез мистецтв у громадській i житловій apхітектурі Галичини першої третини XX ст. URL: http://um.etnolog.org.ua/zmist/2014/158.pdf.

DOI https://doi.org/10.30525/978-9934-26-004-9-124

\section{ДОСЛІДЖЕННЯ СУЧАСНОГО МУЗИЧНОГО МИСТЕЦТВА В АСПЕКТІ «ПАМ'ЯТІ КУЛЬТУРИ»: ДОСВІД КУЛЬТУРОЛОГІЇ}

\author{
Гармель О. В. \\ кандидат мистеитвознавства, доцент, \\ дочент кафедри теорії музики \\ Київської муніщипальної академії музики імені Р. М. Глієра \\ м. Київ, Украӥна
}

Пошук методологічних орієнтирів для дослідження сучасного музичного мистецтва $є$ однією з актуальних проблем мистецтвознавства. Особливого значення це набуває при аналітичному зануренні у твори, в яких композитори на етапі формування задуму свідомо залучають досвід 
музичної культури минулого, вибудовуючи багатошарове смислове поле власного опусу.

При вивченні таких творів більшість мистецтвознавчих дослідницьких стратегій рухається в межах теорії полістилістики крізь призму естетики постмодернізму із залученням положень теорії інтертекстуальності. Разом 3 тим, для усвідомлення усіх тонкощів відбиття у музичному мистецтві сучасних ментальних процесів щодо саморозуміння митця-композитора у потоці музичної історії важливо також активніше залучати досвід культурології, що сформувався від 1980-х років у межах Memory Studies. Адже твори, в яких композитори свідомо осмислюють музичну історію, не лише безпосередньо апелюють до нашої пам'яті як властивості індивідуальної свідомості. Вони відіграють важливу роль у збереженні, осмисленні, трансляції, трансформації і творенні культурної пам'яті у межах колективної свідомості.

Зокрема, актуалізуємо думки двох визнаних класиків культурології, які у своїх роботах звертались до проблематики функціонування пам'яті в культурі - німецького науковця Яна Ассманна («Культурна пам’ять: Письмо, пам'ять про минуле та політична ідентичність у високих культурах давнини» (1992)) та російського дослідника Юрія Лотмана («Пам’ять у культурологічному висвітленні» (1985), «Пам'ять культури» (1986), «Всередині мислячих світів» (1990)). Наведемо думки культурологів, які резонують із сучасною композиторською творчістю.

Я. Ассманн зосереджує увагу на понятті культурна пам'ять як одному із зовнішніх вимірів людської пам'яті. Це «сфера культури, де сплітаються традиція, історична свідомість, “міфомоторика" та самовизначення» [1, c. 24]. У цьому контексті важливою тезою дослідження Я. Ассманна є думка про те, що минуле виникає завдяки зверненню до нього. «Це твердження може спочатку викликати подив. Виникнення минулого здається найприроднішим явищем <... . Однак суспільство може дуже по-різному ставитися до цього природнього процесу. Одні суспільства можуть, як це стверджував Цицерон про "варварів", “жити одним днем" і безтурботно поступатися "сьогодні" минулому, яке означає у цьому випадку зникнення і забуття; інші ж можуть докладати всіх зусиль, щоб надати “сьогодні” тривалості, наприклад, “спрямовуючи всі плани на вічність", як римляни <..>, а також “звертаючи погляд на завтра" i "розміщуючи у своєму серці вимоги вічності”, як єгипетські владики» [1, с. 31-32]. У відповідності $з$ контекстом спогадів про минуле Я. Ассманн пропонує розрізняти комунікативну і культурну пам'ять: 1) комунікативна пам'ять охоплює спогади, пов'язані 3 недалеким минулим; 2) культурна пам'ять 
спрямована на фіксовані моменти у минулому; тут минуле згортається у символічні фігури, до яких «прикріплюється» спогад. Таким чином, для підтримки культурної пам'яті важливою є мнемотехніка і свої особливі носії. «До них відносяться шамани, барди, гріо, а також жреці, вчителі, митці, письменники, вчені <..> та інші, як би не називали у різних культурах цих уповноважених знань» $[1$, с.56]. У культурному пригадуванні завжди присутній елемент сакрального. При цьому пам'ять не лише відтворює минуле, але й організує переживання теперішнього й майбутнього. Завдяки культурній пам'яті людське життя набуває двовимірності: «<..> можливість жити одразу у двох часових пластах належить до універсальних функцій <...> культури як пам'яті» [1, с. 90].

Концепція Ю. Лотмана розгортається навколо розуміння культури як колективного інтелекту, простору загальної колективної пам'яті, в якому можуть зберігатися та 3 часом актуалізуватися певні константні тексти. 3 точки зору якості збереження текстів дослідник пропонує поділяти пам'ять культури на інформативну і креативну (творчу). Якщо інформативна пам'ять (наприклад, у науці) підпорядкована хронології, функціонує у площині розгортання реального часу та характеризується затребуваністю інформації підсумкового, хронологічно останнього зрізу, то креативна пам'ять (зокрема, у мистецтві) має складну структуру, яка не підлягає чіткому визначенню. Найважливіші характеристики креативної (творчої) пам'яті культури такі:

- весь обсяг текстів культури є потенційно активним, а не лише той зріз, що хронологічно наближений до сучасності; у семіотичних аспектах культури спостерігається «постійна актуалізація різних текстів попередніх епох, постійна присутність - свідомо чи несвідомо - у синхронному зрізі культури глибинних, часом досить архаїчних ії станів $<\ldots>\ll[4$, c. 615$]$

- актуалізація тих чи інших текстів не має певних хронологічних закономірностей, а зумовлена складними законами загального культурного руху: «<... минуле не знищується і не зникає в небуття, а, піддаючись відбору і складному кодуванню, переходить на зберігання, щоб при певних умовах знову заявити про себе» [4, с. 615]; таким чином, історія мистецтва розгортається за законами, які нагадують закони пам'яті;

- тексти, які утворюють спільну пам'ять культурного колективу, слугують засобом дешифрування сучасних текстів;

- пам'ять культури відіграє активну роль у породженні нових текстів; у цьому вона « $<. .>$ як творчий механізм не тільки панхронна, але й протистоїть часу. Вона зберігає минуле як таке, що триває» [4, с. 674]; 
- творча пам'ять культури сприяє створенню нових текстів не лише у теперішньому, але й у минулому; це відбувається під впливом нових кодів і зумовлене постійним діалогом між пам'яттю культури та іiі саморефлексією: «<..> деякі тексти з хронологічно більш ранніх пластів вносяться в культуру, взаємодіючі 3 іiі сучасними механізмами, генерують образ історичного минулого, який переноситься культурою у минуле і вже як рівноправний учасник діалогу впливає на теперішнє. Але у світлі трансформованого теперішнього і минуле міняє свій образ» [4, c. 389].

Досвід сучасних українських митців у цій площині $\epsilon$ досить важливим, знаковим і багатоплановим. В аспекті «пам'яті культури» можна пунктиром згадати різні твори українських композиторів останніх десятиліть XX - XXI ст., глибинний зміст яких «виринає» 3 пам'яті музичної культури. Так, концептуальними орієнтирами Симфонієти (1971) Євгена Станковича стають твори С. Прокоф'єва, Г. Малера i Й. С. Баха; ключем до розкриття сенсу його ж Камерної симфонії № 7 (1998) виявляється інструментальна музика А. Вівальді. Олександр Грінберг у п'єсі «House plant» (1993) для камерного ансамбля вибудовує композицію за принципом гри у фактурному лабіринті, де розгадкою гри стає Klavierstück op. 19 № 6 А. Шенберга. Камерна симфонія № 2 «Aria passione» (1992) Ігоря Щербакова, за словами композитора, - це «авторський "емоційний коментар" на арію "Blute nur, du liebes Herz" (№ 12) зі “Страстей за Матфеєм” I. С. Баха, а ширше - на всю монументальну бахівську композицію» [2, с. 36]. Осягнення величного твору I. С. Баха композитор продовжує у камерній симфонії № 3 «Aria passione-2» (2000) крізь призму речитативу та арії альта «Erbarme dich» (№ 47). Перша частина хорового Концерту пам’яті М. Леонтовича (1996) Віктора Степурка несподівано «проростає» 3 алюзії до хору Б. Лятошинського «Осінь» на слова О. Пушкіна (Тв. 47, № 3 ) 3 циклу «Пори року», чим створює «поліфонію пластів» української музичної історії. Сергій Пілютіков в якості тематичного ядра складної симфонічної партитури «Cantus supra librum» (1998) обирає початковий фрагмент з третьої частини мадригалу Палестрини «Есc' oscurati» (партія тенора). Валентин Сильвестров у «Двох діалогах з післямовою» (2002) для струнного оркестру та фортепіано витончено «вслухається» у фортепіанні твори Ф. Шуберта і Р. Вагнера, які стають основою опусу. В апокаліптичних образах масштабного електронно-акустичного проекту Святослава Луньова «Para Pacem - Para Bellum» (2006) актуалізовано конгломерат різних культурних знаків від Нового Завіту до ядерної фізики. У частинах твору, які за змістом $є$ полюсом просвітлення та надії, 
композитор вдається до автоцитування чотирьох п'єс 3 циклу «Мардонги» («21.03.1685 - (І. С. Бах)», «11.09.1962 - (В. Польова)», «11.09.1935 - (А. Пярт)», «Wien.XIX»), а ті, у свою чергу «подібні до стильових варіацій, тема яких майже дослівно співпадає 3 темою "Trällerliedchen" 3 "Альбома для юнацтва" Р. Шумана" [3, с. 18]. Олександр Щетинський у «Землі Франца-Йозефа» (2011) для оркестру відтворює обрис першої частини клавірної сонати Й. Гайдна Es-dur (KH XVI, 49), яка стає основою для творчого осмислення жанру європейської симфонії від класичної доби до сучасних стильових трансформацій.

Загалом, спостереження і висновки культурологічних досліджень в аспекті функціонування пам'яті в просторі культури $\epsilon$ важливим методологічним орієнтиром у розкритті глибинних смислів сучасної композиторської творчості, спрямованої до усвідомлення музичної культури.

\section{Література:}

1. Ассман Я. Культурная память: Письмо, память о прошлом и политическая идентичность в высоких культурах древности / Пер. с нем. М. М. Сокольской. Москва : Языки славянской культуры, 2004. 368 с.

2. Кулик В. В. Творчість Ігоря Щербакова 90-х років XX століття: художня концепція та специфіка індивідуально-стильових пошуків. Кваліфікаційна робота на здобуття ступеня магістра мистецтвознавства. Київ : НМАУ ім. П. І. Чайковського, 2001. 77 с.

3. Латковская Н. Интертекстуальность как фактор организации художественного пространства в фортепианном цикле «Мардонги» С. Лунёва // Київське музикознавство. Вип. 39. Київ : НМАУ ім. П. І. Чайковського, КІМ ім. Р. М. Глієра, 2011. С. 14-23.

4. Лотман Ю. М. Семиосфера. СПб: «Искусство-СПб», 2000. 704 с. 